\title{
Pengaruh Kombinasi Pemberian Tablet Fe dan Jus Jambu Biji terhadap Kenaikan Kadar Hemoglobin Mahasiswi Jurusan Kebidanan
}

\author{
Baiq Eka Putri Saudia ${ }^{1}$, Winda Astria Putri ${ }^{2}$ \\ 1,2 Jurusan Kebianan Poltekkes Kemenkes Mataram, Indonesia
}

\begin{abstract}
Abstrak
Menurut data hasil Riskesdas tahun 2018 presentasi ibu hamil anemia banyak pada usia 15-24 tahun sebesar 84,6\%,usia 25-34 tahun sebesar 33,7\%, usia 35-44 tahun sebesar 33,6\%, dan usia 45-54 tahun sebesar 24\%. Dari data tersebut umur tertinggi ibu hamil yang menderita anemia adalah ibu hamil yang berusia remaja yaitu 15-24 tahun. Penelitian ini bertujuan untuk mengidentifikasi pengaruh pemberian tablet $\mathrm{Fe}$ dan jus jambu biji terhadap kadar hemoglobin mahasiswi Jurusan Kebidanan Poltekkes Kemenkes Mataram. Rancangan penelitian yang digunakan adalah Quasi Eksperiment dengan menggunakan Pre Post Test control Grup Design. Metode pengambilan sampel dalam penelitian ini menggunakan purposive sampling dengan total sampel 30 mahasiwi. Sampel dibagi menjadi 15 orang pada kelompok kontrol diberikan tablet Fe dan 15 orang pada kelompok intervensi diberikan tablet Fe dan jus jambu biji. Data hemoglobin responden dikumpulkan sebelum dan sesudah pemberian intervensi menggunakan Easy Touch Blood Hemoglobin. Analisa data menggunakan uji paired t-test dan independent t-test. Hasil menunjukkan rata-rata kadar hemoglobin mahasiswi yang hanya mendapatkan tablet Fe sebesar 0,20 gr/dL. Rata-rata kadar hemoglobin mahasiswi yang mendapatkan tablet $\mathrm{Fe}$ dan jus jambu biji sebesar $0,76 \mathrm{gr} / \mathrm{dL}$. Hasil uji statistik menggunakan independent $t$ test diperoleh p value yaitu 0,000. Dapat disimpulkan bahwa pemberian Fe kombinasi jambu biji lebih efektif untuk meningkatkan kadar hemoglobin daripada pemberian Fe saja.
\end{abstract}

\section{Kata Kunci: Zat besi; Tablet Fe; Jus Jambu Biji; Hemoglobin; Anemia}

\begin{abstract}
According to the 2018 Riskesdas data, the percentage of pregnant women with anemia was $84.6 \%$, aged 25-34 years was 33.7\%, aged 35-44 years was 33.6\%, and aged 45-54. year by 24\%. From these data, the highest age of pregnant women who suffer from anemia is pregnant women aged 15-24 years. This study aims to identify the effect of giving Fe tablets and guava juice on hemoglobin levels of female students in the Department of Midwifery, Poltekkes, Kemenkes Mataram. The research design used was Quasi Experiment using Pre Post Test control Group Design. The sampling method in this study used purposive sampling with a total sample of 30 students. The sample was divided into 15 people in the control group given Fe tablets and 15 people in the intervention group given Fe tablets and guava juice. The respondent's hemoglobin data was collected before and after the intervention using Easy Touch Blood Hemoglobin. Data analysis used paired t-test and independent $t$ test. The results showed that the average hemoglobin level of female students who only received Fe tablets was $0.20 \mathrm{~g} / \mathrm{dL}$. The average hemoglobin level of female students who received Fe tablets and guava juice was $0.76 \mathrm{gr} / \mathrm{dL}$. The results of statistical tests using independent t test obtained $p$ value of 0.000. It can be concluded that the administration of Fe in combination with guava is more effective in increasing hemoglobin levels than the administration of only $F e$.
\end{abstract}

Keywords: Iron; Fe tablets; Guava juice; Hemoglobin; Anemia 


\section{PENDAHULUAN}

Prevalensi anemia remaja di dunia bervariasi di beberapa negara berkembang berkisar antara 20-70\%. Di negara Myanmar prevalensi anemia ditemukan sebanyak 59.1\% dengan responden 1.269. Peneliti juga menemukan kasus stunting sebanyak 21.2\% dan wasting sebanyak 10.7\% (Htet et al., 2012). Studi penelitian yang dilakukan Chang et al (2008), di Kuala Lumpur, menemukan prevalensi anemia $28,3 \%$ pada remaja putri. Prevalensi anemia yang tertinggi terdapat pada negara berpenduduk terbanyak di dunia yaitu India dengan $\mathbf{7 8 . 7 5 \%}$ dengan kasus terbanyak pada remaja putri dengan ibu yang berpendidikan rendah (Premalatha et al., 2012).

Anemia masih menjadi masalah gizi utama di Indonesia khususnya anemia difisiensi besi, yang banyak dialami oleh anak-anak sekolah khususnya remaja. Data menunjukkan proporsi penduduk dengan keadaan anemia mencapai 21,7\% . Dimana anemia pada perempuan lebih tinggi yaitu 23,9\% dibandingkan pada laki-laki yang hanya $18,4 \%$, dan didapatkan besarnya presentase penderita anemia pada remaja awal putri 10-14 tahun ( $\mathrm{Hb}<12 \mathrm{gr} / \mathrm{dL}$ ) yang berjumlah 26,4\% (Riskesdas, 2013). Menurut data hasil Riskesdas tahun 2018 presentasi ibu hamil anemia banyak pada usia 15-24 tahun sebesar 84,6\%,usia 25-34 tahun sebesar 33,7\%, usia 35-44 tahun sebesar 33,6\%, dan usia 45-54 tahun sebesar $24 \%$. Dari data tersebut umur tertinggi ibu hamil yang menderita anemia adalah ibu hamil yang berusia remaja yaitu 15-24 tahun.

Menurut data hasil dari Dinas Kesehatan Kota Mataram tahun 2017, prevalensi anemia pada remaja putri yaitu 237 pada usia 10-19 tahun. Dari 11 Puskesmas yang berada di wilayah kerja Dinas Kesehatan Kota Mataram terdapat prevalensi anemia tertinggi yaitu di Puskesmas Selaparang sebesar 88 pada usia 10-19 tahun, dan prevalensi anemia terendah yaitu di Puskesmas Cakranegara sebesar 1 pada usia 10-19 tahun (Dikes Kota Mataram,2017). Berdasarkan data hasil wawancara terhadap 94 mahasiswi Jurusan Kebidanan Poltekkes Mataram lebih beresiko terjadinya anemia dikarenakan pola makan yang tidak teratur dan jadwal kuliah yang dimulai dari pagi hingga sore hari dan adanya tambahan praktik sehingga pola istirahat mahasiswi kebidanan Poltekkes Mataram tidak teratur.

Menurut Fiastuti Witjaksono (2014) mengatakan bahwa efektifitas penyerapan Fe bersamaan dengan Vitamin $\mathrm{C}$ alami dari buah-buahan lebih baik dibandingkan penyerapan Fe bersamaan dengan tablet Vitamin $\mathrm{C}$ dosis tinggi. Vitamin $\mathrm{C}$ yang terdapat dari buah-buahan seperti Jambu biji yang kandungan Vitamin C nya sebesar 95/100 gr dibandingkan dengan buah lainnya.Penderita anemia mudah terserang penyakit infeksi sehingga dapat menghambat kualitas sumber daya manusia. Pengaruh vitamin $\mathrm{C}$ terhadap peningkatan kadar hemoglobin didukung oleh penelitian yang dilakukan oleh Wirawan S,dkk (2015) dengan judul penelitian yaitu Pengaruh Pemberian Tablet Besi dan Tablet besi Plus Vitamin C terhadap Kadar Hemoglobin Ibu Hamil. Dari hasil penelitian tersebut didapatkan hasil bahwa ada pengaruh yang bermakna terhadap perubahan kadar hemoglobin dengan pemberian tablet tambah darah $(\mathrm{Fe})$ ditambah dengan vitamin $\mathrm{C}$. 
Hasil penelitian serupa juga dilakukan oleh Utama,dkk (2013) dengan judul penelitian yaitu perbandingan zat besi dengan dan tanpa vitamin $\mathrm{C}$ terhadap kadar hemoglobin wanita usia subur. Nilai rata-rata kadar hemoglobin pada kelompok kontrol pada sebelum intervensi yaitu 9,15 gram/dL dan setelah intervensi meningkat menjadi 10,19 gram/dL. Pada kelompok perlakuan rata-rata kadar hemoglobin sebelum intervensi sebesar 9,5 gram/dL dan meningkat menjadi 11,44 gram/dL sesudah inter- vensi. Hasil uji T berpasangan menunjukkan perbedaan yang signifikan pada nilai mean kadar hemoglobin pada kelompok kontrol dan perlakuan (nilai $\mathrm{p}=0,000$ )

Salah satu buah yang sangat kaya vitamin $C$ adalah Jambu biji. Kandungan Vitamin $C$ pada jambu biji setara dengan 6 kali kandungan vitamin $C$ pada jeruk, 10 kali kandungan vitamin $C$ pada pepaya, 17 kali kandungan vitamin $\mathrm{C}$ pada jambu air, dan 30 kali kandungan Vitamin $\mathrm{C}$ pada pisang. (Hadiati dan Apriyanti, 2015). Pada penelitian Marlina dan Putriyana (2015) terhadap efek pemberian tablet $\mathrm{Fe}$ dan jus jambu biji pada remaja putri yang anemia defisiensi besi yang dilakukan selama 7 hari didapatkan hasil tidak ada perbedaan yang signifikan rata-rata kadar hemoglobin antara kelompok kontrol dan perlakuan. Namun dilihat dari selisih rata-rata antara kelompok kontrol dan perlakuan terjadi kecendrugan peningkatan rata-rata kadar Hb yaitu 0,24 (Marlina dan Putriyana, 2015). Berdasarkan uraian tersebut, penelitian penelitian ini bertujuan untuk mengidentifikasi pengaruh kombinasi pemberian tablet tambah darah dan jus jambu biji teradap kenaikan kadar hemoglobin pada Mahasiswi di Jurusan Kebidanan Poltekkes Kemenkes Mataram.

\section{METODE}

Penelitian ini merupakan penelitian eksperimen semu atau Quasi Experiment, menggunakan Pre Post Test control Grup Design. Metode pengambilan sampel dalam penelitian ini menggunakan purposive sampling dengan total sampel 30 mahasiswi. Sampel dibagi menjadi 15 orang pada kelompok kontrol diberikan tablet $\mathrm{Fe}$ dan 15 orang pada kelompok intervensi diberikan kombinasi tablet Fe dan jus jambu biji. Masing-masing sampel pada kedua kelompok diberikan intervensi selama 14 hari.

Data hemoglobin responden dikumpulkan sebelum dan sesudah pemberian intervensi menggunakan Easy Touch Blood Hemoglobin. Analisa data menggunakan uji paired t-test untuk data sebelum dan sesudah diberikan intervensi pada masing-masing kelompok. Analisa data independent $t$ test digunakan untuk menguji data hemoglobin pada kelompok kontrol dan kelompok intervensi setelah diberikan perlakuan.

\section{HASIL PENELITIAN}

Hasil pengukuran kadar hemoglobin sebelum dan setelah diberikan tablet Fe pada kelompok control dapat dilihat pada tabel 1 berikut ini: 
Tabel 1. Kadar Hemoglobin Sebelum dan Sesudah Diberikan Tablet Fe.

\begin{tabular}{|c|c|c|c|c|c|c|c|}
\hline & & & Mean & $\mathbf{N}$ & SD & Std. Error Mean & $p$ \\
\hline \multirow[b]{2}{*}{$\mathrm{T}$} & \multirow[b]{2}{*}{ Tablet Fe } & Sebelum & 11.840 & 15 & 2849 & .0735 & \\
\hline & & Setelah & 12.047 & 15 & .2924 & .0755 & 0.060 \\
\hline
\end{tabular}

menunjukkan bahwa nilai rerata sebelum diberikan tablet Fe yaitu 11.840 dan nilai rerata setelah diberikan tablet $\mathrm{Fe}$ yaitu 12.047, sedangkan nilai $p$-value $=0.060>\alpha(0,05)$. Hal ini menunjukkan bahwa tidak ada perbedaan yang bermakna rerata kadar hemoglobin pada kelompok kontrol baik sebelum maupun setelah diberikan tablet Fe.

Hasil uji perbedaan rata- rata kadar hemoglobin pada kelompok intervensi sebelum dan setelah di berikan tablet tambah darah (Fe) kombinasi jus jambu biji dapat dilihat pada tabel 2 dibawah ini:

Tabel 2. Kadar Hemoglobin Sebelum dan Setelah Diberikan Kombinasi Tablet Fe dan Jus Jambu Biji

\begin{tabular}{lcccccc}
\hline & & Mean & N & SD & Std. Error Mean & $p$ \\
\hline $\begin{array}{c}\text { Tablet Fe }+ \\
\text { Jambu Biji }\end{array}$ & Sebelum & 11.993 & 15 & .4862 & .1255 & \\
\cline { 2 - 6 } & Setelah & 12.760 & 15 & .5040 & .1301 & \multirow{2}{*}{0.000} \\
\hline
\end{tabular}

Tabel 2 menunjukkan bahwa nilai rerata kelompok intervensi sebelum diberikan tablet $\mathrm{Fe}$ dan kombinasi jus jambu biji yaitu 11.993 dan nilai rerata setelah diberikan tablet $\mathrm{Fe}$ dan kombinasi jus jambu biji yaitu 12.760 , sedangkan nilai $p$-value $=0.000<\alpha(0,05)$. Hal ini menunjukkan bahwa terdapat perbedaan yang bermakna rerata kadar hemoglobin pada kelompok intervensi baik sebelum maupun setelah diberikan kombinasi tablet Fe dan jus jambu biji.

Hasil uji perubahan kadar hemoglobin antara kelompok kontrol yang mengkonsumsi tablet Fe dengan kelompok intervensi yang mengkonsumsi tablet Fe kombinasi jus jambu biji disajikan pada tabel sebagai berikut:

Tabel 3. Hasil Uji Perbandingan Rata-Rata Perubahan Kadar Hemoglobin Antara Kelompok Kontrol Dengan Kelompok Intervensi

\begin{tabular}{cccc}
\hline Kelompok & $\mathbf{N}$ & Means & $\boldsymbol{p}$-value \\
\hline Teblet Fe & 15 & 0,20 & 0.060 \\
\hline Tablet Fe + Jambu biji & 15 & 0,76 & 0.000 \\
\hline
\end{tabular}

Tabel 3 menunjukkan ada perbedaan rerata kenaikan kadar hemoglobin pada kelompok kontrol dan kelompok intervensi. Bila didasarkan nilai rerata terlihat ada peningkatan rerata kadar 
haemoglobin yang signifikan pada kedua kelompok, dimana nilai rata-rata selisih kadar hemoglobin sebelum dan setelah pada kelompok kontrol yaitu 0,20 dengan $p$-value $=0.060>\alpha$ dan rata-rata selisih kadar hemoglobin sebelum dan setelah pada kelonpok intervensi yaitu 0,76 dengan nilai $p$-value $=$ $0.000<\alpha(0,05)$. Hal ini berarti bahwa rerata perubahan kadar haemoglobin pada kelompok intervensi lebih menunjukkan peningkatan yaitu 0,76 dibandingkan dengan kelompok kontrol. Sehingga artinya terdapat pengaruh tablet $\mathrm{Fe}$ dengan kombinasi jus jambu biji terhadap perubahan kadar hemoglobin pada mahasiswi kebidanan.

\section{PEMBAHASAN}

\section{Kadar Hemoglobin Mahasiswi Yang Diberi Tablet Fe}

Hasil penelitian menunjukan bahwa dari uji analisis dengan t-independen di dapatkan nilai rata-rata perubahan kadar hemoglobin sebelum dan sesudah pada kelompok kontrol yang diberi tablet Fe. Sebelum diberikan tablet Fe nilai rerata 11.840 dan nilai rerata setelah diberikan tablet Fe yaitu 12.047 sehingga rerata selisih kenaikan kadar haemoglobin sebesar 0,20. Hasil penelitian tersebut sejalan dengan penelitian yang dilakukan oleh Giynati dkk (2016) dalam penelitiannya tentang pengaruh pemberian tablet Fe terhadap kenaikan kadar haemoglobin remaja putri dengan anemia di SMK Negeri I Pojong Gunung Kidul yang melibatkan 30 responden di peroleh hasil bahwa ada pengaruh kenaikan kadar haemoglobin dengan pemberian tablet Fe didapatkan kenaikan rata-rata yaitu 0,1 dan 0,7. Pada kelompok kontrol naik 40\% dan pada kelompok eksperimen 93,33\%.

Hal ini juga di dukung oleh penelitian yang dilakukan oleh Dwi dkk (2017) yang meneliti tentang pengaruh konsumsi tablet Fe terhadap peningkatan kadar hemoglobin pada remaja putri di SMAN 2 Ngaglik Kabupaten Sleman dengan 30 responden yang diberikan intervensi pemberian tablet Fe selama 30 hari. Hasil penelitian menunjukkan bahwa sebelum pemberian tablet Fe nilai ratarata sebesar 12.76 dan nilai rata-rata setelah pemberian tablet Fe sebesar 13.14, sehingga mengalami kenaikan dengan nilai selisih 0.50. Menunjukkan adanya pengaruh konsumsi tablet Fe terhadap peningkatan kadar hemoglobin pada remaja putri. Sedangkan penelitian yang dilakukan oleh Emut dkk (2018) juga memperoleh hasil penelitian bahwa remaja putri sebelum dilakukan pemberian tablet Fe seluruhnya mengalami anemia ringanaitu 28 orang (100\%), sedangkan sesudah dilakukan pemberian tablet Fe remaja putri tidak mengalami anemia yaitu sebanyak 27 orang (96,4\%). Hasil uji perubahan kadar $\mathrm{Hb}$ diperoleh nilai t-hitung sebesar -13,031 dengan tingkat signifikansi ( $\left.\rho_{\text {value }}\right)$ sebesar 0,000 , yang berarti bahwa ada pengaruh pemberian tablet Fe terhadap perubahan kadar $\mathrm{Hb}$ pada remaja putri.

Uji statistik didapatkan bahwa dalam penelitian ini terdapat pengaruh konsumsi tablet $\mathrm{Fe}$ terhadap peningkatan kadar hemoglobin pada mahasiswi Jurusan Kebidanan Poltekkes Kemenkes 
Mataram. Penelitian ini menunjukkan bahwa ada peningkatan kadar hemoglobin setelah mengkonsumsi tablet $\mathrm{Fe}$. Intervensi yang diberikan pada responden dengan mengkonsumsi tablet $\mathrm{Fe} 1$ kali sehari selama 14 hari sangat membantu untuk menanggulangi anemia zat besi (IDAI, 2011). Pentingnya pemberian zat besi ini kepada seseorang yang sedang mengalami anemia defiseinsi besi dan tidak ada gangguan absorpsi maka dalam 7-10 hari kadar kenaikan hemoglobin bisa terjadi sebesar 1,4 mg/KgBB/hari (IDAI, 2011). Adapun faktor yang mempengaruhi peningkatan kadar hemoglobin pada remaja putri yaitu usia, frekuensi mentruasi, status gizi, pola makan, jenis makanan yang dikonsumsi, konsumsi tablet Fe dan aktivitas fisik.

\section{Kadar Hemoglobin Mahasiswi yang diberikan Tablet Fe kombinasi Jus Jambu Biji.}

Hasil penelitian menunjukan bahwa nilai rerata kelompok intervensi sebelum diberikan tablet Fe dan kombinasi jus jambu biji yaitu 11.993 dan nilai rerata setelah diberikan tablet Fe dan kombinasi jus jambu biji yaitu 12.760, sehingga rerata selisih kenaikan kadar haemoglobin sebesar 0,76 . Sedangkan nilai $p$-value $=0.000<\alpha(0,05)$. Hal ini menunjukkan bahwa terdapat perbedaan yang bermakna rerata kadar hemoglobin pada kelompok intervensi baik sebelum maupun setelah diberikan tablet Fe Kombinasi Jus Jambu Biji. Menurut Wirawan, dkk (2015) Pemberian tablet besi bersamaan dengan zat gizi mikro lain (multiple micronutrients) lebih efektif dalam meningkatkan status besi, dibandingkan dengan hanya memberikan suplementasi besi dalam bentuk dosis tunggal. Oleh karena itu, untuk meningkatkan penyerapan besi di dalam tubuh, suplementasi besi yang diberikan perlu dikombinasi dengan mikronutrien lain, seperti vitamin A dan vitamin $\mathrm{C}$.

Hal ini sejalan dengan penelitian yang dilakukan oleh Pagdya dkk (2018) yang meneliti tentang Pengaruh Pemberian Jus Jambu Biji Merah (Psidium Guajava.L) Terhadap Kadar Hemoglobin dan Ferritin Serum Penderita Anemia Remaja Putri dengan melibatkan 34 orang remaja putri yang dipilih secara simple random sampling. Subjek dibagi menjadi 2 kelompok, kelompok kontrol dan perlakuan. Kelompok perlakuan diberikan 100 gr jambu biji merah yang diolah menjadi jus selama 7 hari. Rerata kadar $\mathrm{Hb}$ pretest 10,26 gr/dl (kontrol) dan 10,50 gr/dl (intervensi) sedangkan rerata kadar $\mathrm{Hb}$ postest $10,98 \mathrm{gr} / \mathrm{dl}$ (kontrol) dan 12,48 gr/dl (intervensi). Hasil uji statistik didapatkan ada pengaruh pemberian jus jambu biji merah terhadap kadar hemoglobin penderita anemia remaja putri dengan nilai $\mathrm{p}=<0,001$. Sedangkan penelitian yang dilakukan oleh Dwi Estuning Rahayu (2020) yang berjudul efektifitas pemberian jus jambu terhadap kadar hemoglobin ibu hamil trimester II dengan anemia mengungkapkan bahwa penggunaan jus jambu biji yang diberikan selama 7 hari dapat menaikkan kadar $\mathrm{Hb}$ ibu hamil sehingga diharapkan pemberian jus Jambu dapat menjadi alternatif dalam mencegah dan menangani anemia ibu hamil.

Hasil dalam penelitian yang telah dilakukan dengan memberikan tablet $\mathrm{Fe}$ dengan kombinasi jus jambu yang diberikan selama 14 hari terbukti dapat meningkatkan kadar haemoglobin mahasiswi 
Jurusan Kebidanan Poltekkes Kemenkes Mataram. Intervensi yang diberikan dalam bentuk jus sangat membantu dalam proses absorbsi karena penyerapannya lebih cepat. Buah yang di jus akan lebih cepat diabsorbsi sistem pencernaan dalam waktu 20 menit sedangkan buah yang tidak dalam bentuk jus membutuhkan waktu sekitar 18 jam. Berpengaruhnya jus jambu biji ini terhadap peningkatan kadar hemoglobin juga dikaitkan oleh kandungan dari jus jambu biji itu sendiri.

\section{Perbedaan Kadar Hemoglobin Mahsiswi Jurusan Kebidanan yang Mendapat Tablet Fe dan Tablet Fe disertai Jus Jambu Biji.}

Berdasarkan hasil analisa menggunakan $t$-independen dapat dilihat bahwa ada perbedaan selisih kenaikan kadar hemoglobin pada kelompok kontrol dan kelompok intervensi dimana nilai rata-rata selisih kadar haemoglobin kelompok kontrol yang diberikan Tablet Fe yaitu 0,20 mg/dl di bandingkan dengan kelompok Tablet Fe disertai Jus Jambu Biji dimana perubahan nilai rata-rata yaitu 0,76 mg/dl dengan nilai $\mathrm{p}$-value $=0,000<\alpha(0,05)$, artinya terdapat pengaruh tablet Fe kombinasi jus jambu biji terhadap perubahan kadar hemoglobin pada Mahasiwi Jurusan Kebidanan yang lebih signifikan.

Hasil penelitian ini sejalan dengan hasil Yusnaini (2014) yang menyatakan bahwa ada perbedaan kadar hemoglobin pada kelompok Ibu hamil yang mendapat suplementasi tablet Fe dengan kelompok yang mendapat suplementasi Fe dan mengkonsumsi jus jambu biji (100 gram jambu biji). Di dukung pula oleh penelitian yang di lakukan oleh Siti Rahma Safitri (2018) menunjukan bahwa pemberian Fe kombinasi jambu biji lebih efektif untuk meningkatkan kadar hemoglobin ibu hamil yang di tunjukan dengan nilai $\mathrm{p}$-value $=0,001<\alpha(0,05)$.

Makanan yang kaya zat besi dan jus jambu biji dapat membantu proses penyerapan zat besi dan mampu mengobati penyakit anemia pada remaja putri. Buah jambu biji mengandung senyawa yang dapat meningkatkan kadar hemoglobin dalam darah, antara lain: zat besi, vitamin C, vitamin A, tembaga dan fosfor. Zat besi yang terkandung dalam bahan makanan akan diserap dengan bantuan vitamin C. Vitamin C dapat membantu mereduksi besi ferri $(\mathrm{Fe} 3+)$ menjadi ferro (Fe2+) dalam usus halus sehingga mudah diserap tubuh, proses reduksi tersebut akan semakin besar jika $\mathrm{pH}$ didalam lambung semakin asam. Vitamin $\mathrm{C}$ dapat meningkatkan $\mathrm{pH}$ didalam lambung sehingga dapat meningkatkan proses penyerapan zat besi hingga 30\%. Vitamin C berperan memindahkan zat besi dari transferin yang ada didalam plasma ke ferritin hati. Sebagian besar transferin darah membawa zat besi ke sumsum tulang sebagai cadangan besi dan bagian tubuh lainnya (Sianturi, 2012).

Selain pada ibu hamil jus jambu biji juga dapat meningkatkan kadar hemoglobin pada saat menstruasi hal tersebut dibuktikan dengan adanya penelitian yang dilakukan oleh Sulistiyowati (2015) hasil penelitian tersebut menunjukkan bahwa terdapat pengaruh jus jambu biji terhadap kadar Hemoglobin saat menstruasi dengan $p$-value $=0,000$. Penelitian ini dilakukan pada mahasiswi tingkat 2 Prodi DIII Kebidanan Stikes Muhamadiyah Lamongan yang mengalami anemia saat menstruasi 
dengan memberikan intervensi berupa pemberian jus jambu biji merah sebanyak 400 gram diberikan selama 3 hari pertama menstruasi.

Menurut asumsi peneliti konsumsi tablet Fe kombinasi jambu biji yang diberikan dalam bentuk jus seperti jus buavita sangat membantu dalam proses absorbsi karena penyerapannya lebih cepat dibanding konsumsi Fe sacara tunggal. Dimana peneliti melakukan intervensi selama 14 hari secara berturut-turut dengan membandingkan kedua kelompok yaitu kelompok kontrol dan kelompok perlakuan. Kelompok kontrol mengkonsumsi Fe saja dan pada kelompok perlakuan di beri $\mathrm{Fe}$ kombinasi jus jambu biji. Dan hasilnya terdapat perubahan yang signifikan pada kelompok intervensi dibanding kelompok kontrol.

Penelitian ini memilih jambu biji karena menurut Rhamnosa, (2008) Vitamin C yang terkandung dalam jambu biji memperbesar penyerapan zat besi oleh tubuh, sehingga tubuh di harapkan dapat menyerap zat besi secara optimal dan meningkatkan kadar hb dalam tubuh. Dimana pada jambu biji mengandung asam askorbat 2 kali lipat dari jeruk yaitu sekitar 87 mg/100 gram jambu biji. Selain itu setiap 100 gram jambu biji juga mengandung Kalori 49 kal, Protein 0,9 gram, Lemak 0,3 gram, Karbohidrat 12,2 gram, Kalsium $14 \mathrm{mg}$, Fosfor $28 \mathrm{mg}$, Besi 1,1 mg, Vitamin A 25 SI, Vitamin B1 0,05 mg dan Air 86 gram. Waktu yang digunakan pada penelitian ini adalah 14 hari dimana berdasarkan penelitian yang dilakukan oleh Andiyani (2017) waktu yang digunakan untuk melihat perubahan hemoglobin yaitu 7 hari, dan dapat dilihat perubahan yang signifikan antara kelompok kontrol dan perlakuan dengan nilai $p$-value $=0,026<\alpha(0,05)$.

\section{KESIMPULAN}

Berdasarkan penelitian yang telah dilakukan maka dapat disimpulkan bahwa pemberian tablet Fe dikombinasikan dengan jus jambu biji efektif meningkatkan kadar hemoglobin, lebih baik daripada hanya dengan pemberian tablet Fe saja. Pemberian jus jambu batu untuk mendampingi pemberian tablet $\mathrm{Fe}$ dapat dilakukan sebagai tindakan untuk mendapatkan hasil yang lebih baik dalam penanganan anemia pada mahasiswi atau remaja wanita pada umumnya

\section{DAFTAR PUSTAKA}

Adyani, I, K., Yulinah. E., Sigit J. I. K., Fisheri N., Insanu M., 2004, Efek Ekstrak Daun Jambu Biji Daging Buah Putih dan Jambu Biji Daging Buah Merah sebagai Antidiare, Acta Pharmaceutica Indonesia, (1).

Emut ,HM., Siti,SM., Endang, A .(2018) . Pengaruh Pemberian Tablet Fe Terhadap Perubahan Kadar Hb Pada Remaja Putri di Pondok Pesantren Miftahulkhoertasikmalaya tahun 2018.

Hadiati \& Apriyanti.(2015). Bertanam Jambu Biji di Pekarangan. Jakarta: Agriflo. 
Marlina, H., \& Putriyana, W. (2015). Pemberian Tablet Fe dan Jus Jambu Biji pada Remaja Putri

Premalatha, T., Valarmathi, S., Parameshwari, S., Jasmine, S.S., Kalpana, S., (2012). Prevalence of Anemia and its Associated Factors among Adolesent School Girls In Chennai, Tammil Nadu, India. Epidemiology Open Access.(Online), Vol.2 No.2, (http://dx.doi.org.10.4172/21611165.1000.118, diakses 14 Januari 2020).

Profil Kesehatan Dinas Kesehatan Kota Mataram, 2019.

Rhamnosa. 2008. Kenali Si Vitamin C.http://rhamnosa.wordpress.com. 12 Maret 2018 (14.11)

Riskesdas. 2013. Badan Penelitian dan Pengembangan Kesehatan Kementerian Kesehatan RI. 2013. Riset Kesehatan Dasar (RISKESDAS) tahun 2013.

Sianturi, C. 2012. Pengaruh Vitamin C pada Penyerapan Zat Besi Non Heme.Medan: FMIPA UNM.

Supplementation in Adolescent Girls - An Effective Nutritional Measure for the Management of Iron Deficiency Anaemia. Diakses tanggal 21Januari 2020 dari http://dx.doi.org/10.5539/gjhs.v5n3p188 Survey of Iron Suplementation Consumption and its Related Factors inHigh School Students in Southeast Iron, 2015. Diakses tanggal 21 Januari 2020 dari http://dx.doi.org/10.21315/mjms2016.23.5.8

Utama, T. A., Listiana, N., \& Susanti, D. (2013).Perbandingan Zat Besi dengan dan Tanpa Vitamin C terhadap Kadar Hemoglobin Wanita Usia Subur Comparison Effect of Iron with and without Vitamin C to Age Hemoglobin Levels among Women of Reproductive Age. Jurnal Kesehatan Masyarakat Nasional, 7(8), 344-348.

Wirawan, Susilo. dkk. 2015 Pengaruh Pemberian Tablet Besi dan TabletBesi Plus Vitamin C Terhadap Kadar Hemoglobin Ibu Hamil.

Wirawan, dkk.2015. Pengaruh Tablet Besi Dan Tablet Besi Plus Vitamin C Terhadap Kadar Hemoglobin Ibu Hamil. Bulletin Penelitian System Kesehatan. Vol. 18. No. 3

Witjaksono. (2014). Vitamin c pada buah lebih bagus ketimbang suplemen. http:// www.suara.com/health/2014/12/06/170000/ vitamin-c-pada-buah-lebih-bagusketimbangsuplemen. diakses 07 Januari 2020

Yusnaini.2014. Pengaruh Konsumsi Jambu Biji (Psidium Guajava.L)Terhadap Perubahan Kadar Hemoglobin Pada Ibu Hamil Anemia Yang Mendapat Suplementasi Tablet Fe (Studi Kasus Kasus Ibu Hamil di Wilayah Kerja Puskesmas Kecamatan Indrapuri Kabupaten Aceh Besar Propinsi Aceh). Tesis Program Pascasarjana Undip. 